\title{
STUDI LITERATUR: UPDATE PELAKSANAAN ORAL CARE PADA PASIEN YANG TERPASANG VENTILASI MEKANIK DI RUANG ICU
}

\author{
Diah Tika Anggraeni1), Mareta Dea Rosaline ${ }^{2)}$ \\ 1),2) Fakultas Ilmu Kesehatan Universitas Pembangunan Nasional “Veteran” Jakarta
}

\begin{abstract}
ABSTRAK
Pasien dengan ventilasi mekanik akan mengalami stress oral seperti hilangnya substansi protektif gigi, gangguan fungsi mukosiliari dan perubahan komposisi flora oral. Masalah kesehatan mulut tersebut berpotensi terjadinya kolonisasi bakteri penyebab Ventilator-associated pneumonia, padahal Ventilator-associated pneumonia menjadi salah satu penyebab terbesar mortalitas di ICU. Tujuan: Untuk mengidentifikasi hasil penelitian terbaru tentang pelaksanaan oral care pasien terpasang ventilasi mekanik. Metode: Penelaahan dilakukan berdasarkan content analysis. Pencarian dibatasi pada artikel yang dipublish dari tahun 2009-2017 dengan jenis penelitian Randomised-controlled trial maupun kuasi eksperimen dalam bahasa inggris. Database yang digunakan adalah CINAHL, pubmed, MEDLINE, Proquest dan Sciencedirect dengan kata kunci oral care, oral hygiene, mouth care, mechanically ventilated, intubated, critical care dan intensive care. Hasil: Didapatkan sepuluh artikel tentang efektifitas Chlorhexidine gluconate sebagai agen antimikroba dengan konsentrasi dan volume yang bervariasi. Teknik pelaksanaan oral care yang paling efektif adalah dengan cara toothbrushing dengan frekuensi sesuai dengan skor pengkajian mulut. Selain itu, direkomendasikan pemberian moisturizer untuk menjaga integritas mukosa. Beberapa alat pengkajian kesehatan mulut yang dapat digunakan adalah Oral Assessment Guide, Beck Oral Assessment Scale atau Mucosal-Plaque Score. Kesimpulan: Pelaksanaan oral care secara komprehensif dapat memperbaiki kesehatan mulut pasien dengan ventilasi mekanik, sehingga kolonisasi bakteri penyebab Ventilator-associated pneumonia dapat dicegah. Oleh karena itu, perawat perlu memahami dan mengaplikasikan instrumen pengkajian mulut sebagai dasar pemberian intervensi.
\end{abstract}

Kata kunci: intensive care unit, kesehatan mulut, oral care, ventilasi mekanik

\begin{abstract}
Patients with mechanical ventilation will experience oral stress such as protective dental substance damage, impaired of mucociliary function and changes of oral flora composition. Those oral health problems cause the risk of the development of ventilator-associated pneumonia. Ventilator-associated pneumonia is the main cause of mortality in ICU. Objective: The purpose of this literature review is to identify the current evidence about oral care for the mechanically ventilated patients. Method: Literature review using content analysis. Searching literature is restricted to articles published from 2009-2017 with randomized controlled trial and quasi-experimental design using database CINAHL, pubMed, MEDLINE, Proquest, and Sciencedirect with keywords of oral care, oral hygiene, oral care, mechanical ventilation, intubation, critical care, and intensive care. Results: There are ten articles about the effectiveness of Chlorhexidine gluconate as an antimicrobial agent with varying concentrations and volumes. The most effective oral care technique is toothbrushing with frequency based on the oral assessment score. The application of moisturizer to maintain the integrity of oral mucosa is important. There are several oral health assessment tools, such as Oral Assessment Guide, Beck Oral Assessment Scale or Mucosal-Plaque Score. By utilizing comprehensive oral care, the oral health of mechanically ventilation patients may increase and the risk of colonization causing Ventilator-associated pneumonia can be prevented. Therefore, it is
\end{abstract}


important for critical care nurses to use oral assessment tools as basic guidance giving the intervention.

Keywords: intensive care unit; mechanical ventilation; oral care; oral health

Alamat Korespondensi: FIKES UPN Veteran Jakarta, Jalan Limo Raya Kelurahan Limo Kecamatan

Limo Kota Depok Kode Pos 16515, Telp. 021-7532884, Fax 021-7546772

Email: diahtika@upnvj.ac.id

\section{PENDAHULUAN}

Oral care merupakan salah satu bagian integral dari perawatan pasien di ruang ICU, terutama pasien dengan intubasi trakea. Tindakan intubasi memang dibutuhkan dalam support ventilasi, tetapi tindakan ini juga menjadi jalan masuk mikroorganisme patogen ke paru-paru (Fitch et al, 1999). Tingkat kerentanan yang tinggi pada pasien ICU terhadap infeksi nosokomial menyebabkan pengkajian, intervensi dan strategi pencegahan infeksi menjadi komponen yang sangat penting (Berry, 2007). Chaste \& Fagon (2002) menyebutkan bahwa penyebab utama kematian akibat infeksi nosokomial di ICU adalah Ventilator-associated pneumonia (VAP).

Flora normal pada rongga mulut terdiri dari 350 jenis bakteri dengan tempat kolonisasi yang berbeda. Sebagai contoh, Streptococcus mutans, Streptococcus sanguis, Actinomyces viscosus, dan Bacteroides gingivalis berkolonisasi di gigi, sedangkan Streptococcus salivaris berkolonisasi di lidah (Bagg et al, 2006). Kondisi pasien kritis dengan berbagai gangguan fungsi menyebabkan hilangnya substansi protektif pada permukaan gigi yang disebut fibronectin. Hal ini dapat menjadi tempat yang kondusif bagi organisme patogen seperti Pseudomonas aeruginosa untuk berkoloni (Gibbons, 1989). Organisme yang menempel pada permukaan gigi tersebut akan menyatu untuk membentuk biofilm dan pada perkembangannya akan membentuk plak gigi (Bagg et al, 2006). Plak gigi ini menjadi sumber infeksi yang memerlukan mekanika perusakan selama oral care (American Dental, 2015; Fitch, 1999). Houstan (2002), DeRiso (1996), dan Berry (2007) telah membuktikan bahwa oral hygiene memiliki hubungan yang erat dengan penurunan kolonisasi plak pada gigi dalam pencegahan VAP.

Sejak tahun 2005, Institute for Healthcare Improvement (IHI) telah mendeklarasikan pelaksanaan VAP Bundle untuk mengurangi mortalitas pasien dengan ventilasi mekanik di ruang ICU. Oral care merupakan salah satu dari 5 komponen VAP bundle tersebut, sehingga pelaksanaan oral care pasien di ICU sangat substansial. Akan tetapi, hasil penelitian Grap et al (2003) menunjukkan bahwa perawat di ICU menganggap oral care merupakan tindakan yang tidak terlalu penting dalam mendukung perbaikan pasien. Padahal American Association of Critical Care Nurse (AACN) dan Centers for Disease Control and Prevention (CDC) juga menekankan bahwa program oral care yang komprehensif menjadi salah satu strategi utama dalam pencegahan VAP (Pear, et al, 2007). Meskipun demikian, evidence tentang praktik oral hygiene yang spesifik pada pasien yang terpasang ventilasi mekanik di ICU masih terbatas (Berry et al, 2007).

Hasil penelitian Ibrahim (2015) menunjukkan bahwa hanya 20\% perawat di ruang ICU yang melakukan tindakan oral care sesuai dengan standard. Ames (2011) menyebutkan belum dipahaminya alat pengkajian oral untuk menentukan frekuensi dan prosedur spesifik pada pasien dengan ventilasi mekanik. Sehingga sebagian besar perawat masih melakukan oral care tanpa menggunakan alat ukur, melakukan dengan metode dan frekuensi yang berbeda-beda walaupun dalam satu unit ICU (Soh, 2012). Hal ini menunjukkan bahwa pelaksanaan oral care pada pasien ICU yang terpasang ventilasi mekanik masih perlu diidentifikasi sesuai dengan evidence-based terbaru (Tablan et al, 2004). 
Tujuan dari literatur review ini adalah mengidentifikasi evidence terbaru tentang pelaksanaan oral care pada pasien yang terpasang ventilasi mekanik di ruang ICU.

\section{METODE PENELITIAN}

Pemilihan artikel yang direview berfokus pada jenis penelitian eksperimental baik Randomized-controlled trial (RCT) maupun kuasi eksperimental study. Hal ini dikarenakan masih terbatasnya penelitian RCT tentang oral care pada pasien dengan ventilasi mekanik di Ruang ICU. Artikel yang dipilih meliputi penelitian tentang cara pelaksanaan, alat pengkajian, serta larutan yang digunakan dalam pelaksanaan oral care.

Artikel yang direview dibatasi pada artikel dengan sampel pasien dewasa di ruang ICU yang diintubasi dan mendapatkan ventilasi mekanik. Outcome dari review ini adalah pengaruh dari oral care terhadap kesehatan mulut yang mencakup jumlah bakteri, plak gigi, skor pengkajian oral, maupun terhadap insiden VAP.

Studi literature ini disusun dari penelitian-penelitian yang dipublikasikan secara online. Pencarian dilakukan pada bulan April-Mei 2017 dengan kriteria pencarian meliputi artikel publikasi menggunakan bahasa inggris dan dipublikasikan dari tahun 2009-2017. Database yang digunakan adalah CINAHL, pubmed, MEDLINE, Proquest dan Sciencedirect dengan kata kunci "oral care", "oral hygiene", "mouth care', "mechanically ventilated", "intubated"," critical care" dan "intensive care".

\section{HASIL DAN PEMBAHASAN}

Artikel yang didapatkan sebanyak 32 artikel jurnal publikasi, akan tetapi pada populasi yang berbeda, yaitu oral care pada pasien onkologi. Sebagian besar artikel yang didapatkan berbentuk review terkait dengan efektifitas larutan yang digunakan untuk oral care pasien di ICU dalam pencegahan VAP. Selain itu, jenis penelitian randomized control trial sangat terbatas karena sebagian besar desain penelitian yang ditemukan adalah observasional study. Setelah dilakukan screening terhadap artikel - artikel yang ditemukan, maka peneliti mendapatkan 10 artikel yang sesuai dengan tujuan literature review.

Artikel yang didapatkan berisi efektifitas jenis, volume dan bentuk larutan yang direkomendasikan untuk oral care serta teknik dan waktu pelaksanaan oral care. Beberapa artikel menyebutkan oral assessment yang dapat digunakan oleh perawat ICU dalam mengkaji serta menentukan intervensi oral care pada pasien ventilasi mekanik. Selain itu, sebagian besar artikel membahas tentang bagian-bagian rongga mulut yang menjadi fokus pada pelaksanaan oral care pasien dengan ventilasi mekanik. 
Tabel 1. Deskripsi Artikel yang Direview

\begin{tabular}{|c|c|c|c|c|}
\hline $\begin{array}{c}\text { Peneliti, tahun, } \\
\text { tempat penelitian }\end{array}$ & Desain & $\begin{array}{c}\text { Jumlah } \\
\text { Responden }\end{array}$ & Prosedur Intervensi & Hasil \\
\hline $\begin{array}{l}\text { De Lacerda Vidal, } \\
\text { et al (2017) } \\
\text { Brazil }\end{array}$ & $\begin{array}{l}\text { Prospective, } \\
\text { randomized } \\
\text { study }\end{array}$ & 213 & $\begin{array}{l}\text { - Pasien diberikan protocol standard pencegahan } \\
\text { VAP, meliputi mempertahankan posisi } \\
\text { semirekumben dengan HOB } \geq 30^{\circ} \text {, profilaksis } \\
\text { perdarahan GI, profilaksis DVT serta interupsi } \\
\text { sedasi tiap hari untuk mengkaji kesiapan } \\
\text { ekstubasi. } \\
\text { Kelompok kontrol : Oral hygiene tiap } 12 \text { jam } \\
\text { dengan swab Chlorhexidine gluconate sebanyak } 15 \\
\text { ml } \\
\text { Kelompok intervensi : Oral hygiene tiap } 12 \text { jam } \\
\text { dengan toothbrushing pada gigi, lidah dan mukosa } \\
\text { dengan menggunakan sikat pediatric dengan } \\
\text { bulu lembut dengan gel gigi } 0,12 \text { Chlorhexidine } \\
\text { gluconate, kemudian dilakukan suction }\end{array}$ & 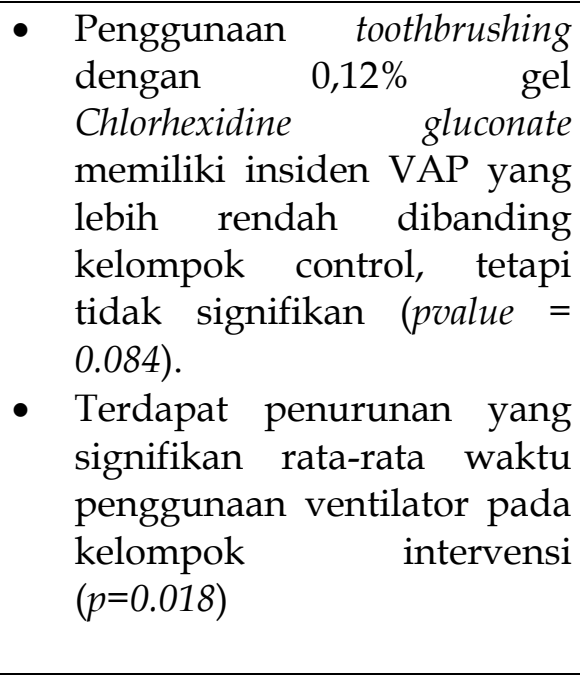 \\
\hline $\begin{array}{c}\text { Grap, et al (2011) } \\
\text { Virginia }\end{array}$ & $\begin{array}{l}\text { Randomized } \\
\text { controlled } \\
\text { trial }\end{array}$ & 145 & $\begin{array}{l}\text { - Kelompok kontrol: mendapatkan oral care sesuai } \\
\text { kebiasaan ruangan (tanpa menggunakan larutan } \\
\text { CHX) } \\
\text { - Kelompok intervensi: swab oral care dengan } \\
\text { Chlorhexidine gluconate (CHX) } 0,12 \% \text { sebanyak } 5 \\
\text { cc, kemudian diberikan oral rinse } \mathrm{CHX} \text { sebanyak } 5 \\
\text { cc pula. Oral care dilakukan maksimal } 12 \text { jam } \\
\text { awal setelah intubasi trakea }\end{array}$ & $\begin{array}{l}\text { - CHX } 0,12 \% \text { pada } 12 \text { jam awal } \\
\text { intubasi trakea efektif dalam } \\
\text { menurunkan skor CPIS pada } \\
48 \text { jam }(p=0.020) \text { sampai } 72 \\
\text { jam }(p=0,027) \text { pasca intubasi. } \\
\text { - Insiden VAP pada kelompok } \\
\text { control sebesar } 55,6 \% \text {, } \\
\text { sedangkan kelompok } \\
\text { intervensi hanya 33,3\%. }\end{array}$ \\
\hline $\begin{array}{l}\text { Lorente, et al (2012) } \\
\text { Spanyol }\end{array}$ & $\begin{array}{l}\text { Randomized } \\
\text { clinical trial }\end{array}$ & 436 & $\begin{array}{l}\text { - Kelompok tanpa toothbrushing : oral care dengan } \\
\text { 0,12\% Chlorhexidine gluconate diberikan tiap } 8 \text { jam, } \\
\text { kemudian di injeksikan 0,12\% Chlorhexidine } \\
\text { gluconate sebanyak } 10 \mathrm{cc} \text { kedalam mulut selama } \\
30 \text { detik, kemudian dilakukn suction } \\
\text { - Kelompok toothbrush: oral care dilakukan seperti } \\
\text { kelompok oral hygiene, akan tetapi setelah }\end{array}$ & $\begin{array}{l}\text { - } \text { Tidak ada perbedaan insiden } \\
\text { VAP antara kedua kelompok } \\
(p=0,75) \\
\text { - Tidak ada perbedaan antara } \\
\text { kelompok toothbrushing dan } \\
\text { tanpa toothbrushing pada } \\
\text { pasien surgical (OR=0,85), }\end{array}$ \\
\hline
\end{tabular}




\begin{tabular}{|c|c|c|c|c|}
\hline & & & $\begin{array}{l}\text { pemberian Chlorhexidine gluconate dilakukan } \\
\text { toothbrushing pada gigi, gusi dan lidah selama } 90 \\
\text { detik }\end{array}$ & $\begin{array}{l}\text { pasien medical }(\mathrm{OR}=0,93) \text {, } \\
\text { dan trauma }(\mathrm{OR}=0,72)\end{array}$ \\
\hline $\begin{array}{l}\text { Berry,et al (2010) } \\
\text { Sidney, Australia }\end{array}$ & $\begin{array}{c}\text { Single blind } \\
\text { Randomized } \\
\text { Controlled } \\
\text { trial }\end{array}$ & 109 & $\begin{array}{l}\text { - Grup A : dilakukan oral rinse tiap } 2 \text { jam dengan } \\
\text { sterile water } \\
\text { - Grup B : mouth wash dengan sodium bikarbonat } \\
\text { tiap } 2 \text { jam } \\
\text { - Grup C : irigasi dengan } 0,2 \% \text { Chlorhexidine } \\
\text { gluconate } 2 x / \text { hari dan irigasi dengan sterile water } \\
\text { tiap } 2 \text { jam }\end{array}$ & $\begin{array}{l}\text { - Insiden VAP terjadi pada } \\
\text { setiap grup (Grup B\&C : 5\%, } \\
\text { sedangkan grup C: } 1 \% \text { ) }\end{array}$ \\
\hline $\begin{array}{l}\text { Prendergast, et al } \\
\qquad(2012) \\
\text { USA }\end{array}$ & $\begin{array}{l}\text { Randomized } \\
\text { Controlled } \\
\text { trial }\end{array}$ & 56 & $\begin{array}{l}\text { - Kelompok standard : suction sebelum } \\
\text { pelaksanaan oral care, posisi HOB } \geq 30 \text {, posisi } \\
\text { semirekumben, toothbrushing dengan sikat gigi } \\
\text { manual selama } 2 \text { menit, pengkajian perdarahan } \\
\text { selama tindakan toothbrush,mouthrinse } 30-60 \text { cc } \\
\text { larutan Normal sterile saline (NSS), pemberian } \\
\text { lubrikan pada bibir, kaji pasien tiap 2-4 jam } \\
\text { terhadap xerostomia } \\
\text { Kelompok komprehensif : suction sebelum } \\
\text { pelaksanaan oral care, posisi HOB } \geq 30 \text {, posisi } \\
\text { semirekumben, toothbrushing dengan sikat gigi } \\
\text { elektrik, penggunan pasta gigi menggunakan } \\
\text { Biotene, pengkajian perdarahan selama tindakan } \\
\text { toothbrush,sikat ETT dengan hati-hati, mouthrinse } \\
\text { dengan } 30-60 \text { cc NSS, berikan Biotene swab pada } \\
\text { jaringan mulut, berikan moisturizer oral balance } \\
\text { pada bibir, kaji pasien tiap 2-4 jam terhadap } \\
\text { xerostomia, berikan moisturizer pada pipi bagian } \\
\text { dalam \& lidah jika diperlukan } \\
\text { Pengkajian oral dengan Oral Assessment Guide } \\
\text { (OAG) modifikasi dari Eiler yang terdiri dari } 8 \\
\text { kategori : menelan, bibir, lidah, saliva, membrane } \\
\text { mukosa, gingival, gigi dan bau mulut }\end{array}$ & 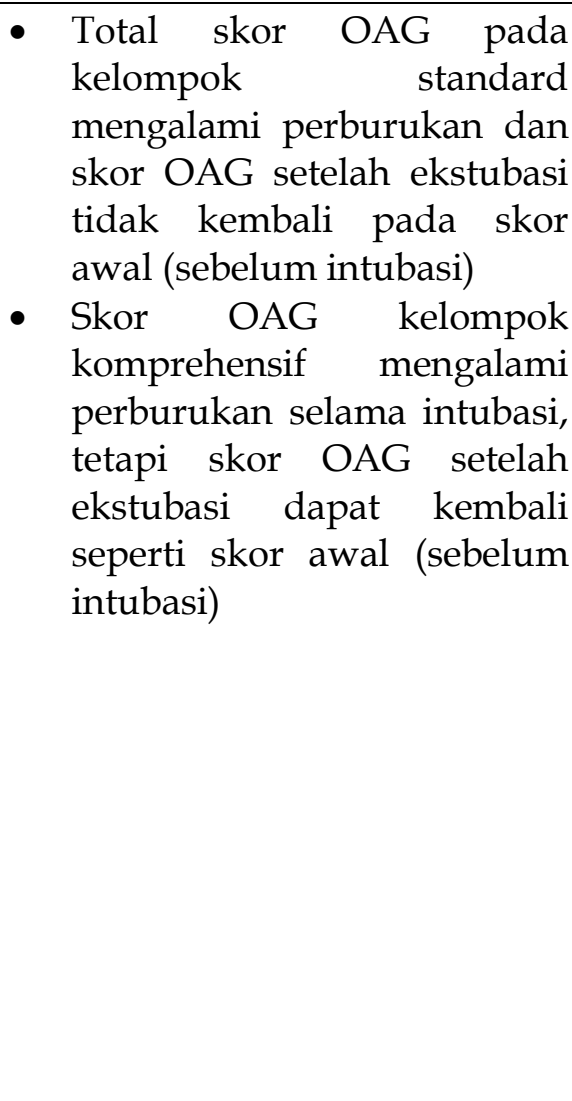 \\
\hline
\end{tabular}




\begin{tabular}{|c|c|c|c|c|}
\hline $\begin{array}{c}\text { Ames, et al (2011) } \\
\text { USA }\end{array}$ & $\begin{array}{l}\text { Multicenter } \\
\text { study, pre- } \\
\text { post design }\end{array}$ & 116 & $\begin{array}{l}\text { - Frekuensi pelaksanaan oral care berdasarkan hasil } \\
\text { pengkajian Beck Oral Assessment Score (BOAS), } \\
\text { tetapi minimal dilakukan tiap } 12 \text { jam } \\
\text { - Systematic oral care meliputi pengkajian BOAS dan } \\
\text { Mucosal-Plaque Score (MPS), pengkajian bleeding } \\
\text { sebelum toothbrushing, ETT care dengan sikat atau } \\
\text { kassa, toothbrushing dengan sikat gigi pediatric } \\
\text { (pasien non-intubasi) atau sikat gigi ultrasoft } \\
\text { (pasien intubasi), pemberian Chlorhexidine } \\
\text { gluconate spray 0,12\% pada gigi dan mukosa, } \\
\text { pemberian moisturizer dengan biotene atau air } \\
\text { biasa. }\end{array}$ & $\begin{array}{l}\text { - } \text { Terdapat perbedaan skor } \\
\text { BOAS secara signifikan } \\
\text { antara kelompok intervensi } \\
\text { dengan kelompok control } \\
(p=0,01) \\
\text { - Skor MPS berbeda secara } \\
\text { signifikan antara kelompok } \\
\text { intervensi dengan control } \\
(p<0,001)\end{array}$ \\
\hline $\begin{array}{c}\text { Liao, et al (2014) } \\
\text { Taiwan }\end{array}$ & $\begin{array}{c}\text { Kuasi } \\
\text { Experimental } \\
\text { study }\end{array}$ & 199 & $\begin{array}{l}\text { - Kelompok kontrol : melakukan pengecekan dan } \\
\text { mempertahankan cuff ETT } 20-24 \text { mmHg setiap } \\
\text { hari, oral care dilakukan dengan menggunakan } \\
\text { sponge dan air biasa, tidak dilakukan oral } \\
\text { assessment, HOB <15 derajat } \\
\text { - Kelompok Intervensi: pengecekan tekanan cuff } \\
\text { tiap } 8 \text { jam dan dipertahankan pada tekanan } 20-24 \\
\text { mmHg, dilakukan pengkajian oral dengan } \\
\text { Barnason's Oral Assessment Guide (OAG) tiap } 8 \\
\text { jam, oral care dilakukan minimal selama } 5 \text { menit } \\
\text { dengan } 0,2 \% \text { Chlorhexidine gluconate sebanyak } 15- \\
20 \text { ml dengan sikat gigi pediatric, HOB } \\
\text { dipertahankan } 30 \text {. }\end{array}$ & $\begin{array}{l}\text { - Terdapat perbedaan insiden } \\
\text { VAP yang signifikan antara } \\
\text { kelompok kontrol dengan } \\
\text { kelompok intervensi (pvalue= } \\
0,004) \\
\text { - Laju perkembangan bakteri } \\
\text { berbeda secara signifikan } \\
\text { (pvalue=0,043) } \\
\text { - Nilai OAG kelompok } \\
\text { intervensi berbeda secara } \\
\text { signifikan antara kelompok } \\
\text { control dengan intervensi } \\
(p<0,05)\end{array}$ \\
\hline $\begin{array}{c}\text { Estaji, Zahra, et al } \\
\text { (2016) } \\
\text { Iran }\end{array}$ & $\begin{array}{l}\text { The clinical } \\
\text { trial study }\end{array}$ & 30 & $\begin{array}{l}\text { - Kelompok kontrol : oral care dilakukan tiap } 8 \text { jam } \\
\text { dengan menggunakan swab chlorhexidine } 2 \% \\
\text { selama } 2 \text { menit. } \\
\text { - Kelompok intervensi: dilakukan toothbrushing } \\
\text { dengan sikat gigi anak yang lembut pada gigi } \\
\text { bagian internal maupun eksternal, gusi, lidah, } \\
\text { palatum. Kemudian mulut dibersihkan degan } \\
\text { sterile water. }\end{array}$ & $\begin{array}{l}\text { - Adanya hubungan antara } \\
\text { toothbrush dengan tingkat } \\
\text { kesehatan oral dengan } \\
\text { menggunakan BOAS dan } \\
\text { MPS (OR:1.52) } \\
\text { - Tidak ada perbedaan yang } \\
\text { signifikan pencegahan lesi } \\
\text { pada gusi, lidah dan bibir }\end{array}$ \\
\hline
\end{tabular}




\begin{tabular}{|c|c|c|c|c|}
\hline & & & & $\begin{array}{l}\text { antara kedua kelompok } \\
\text { - Ada perbedaan yang } \\
\text { signifikan plak, mukosa dan } \\
\text { gigi antara kedua kelompok }\end{array}$ \\
\hline $\begin{array}{c}\text { Berry (2013) } \\
\text { Sidney, Australia }\end{array}$ & $\begin{array}{c}\text { A } \\
\text { Prospective, } \\
\text { Single Blind } \\
\text { Randomised } \\
\text { Comparative } \\
\text { Study }\end{array}$ & 398 & 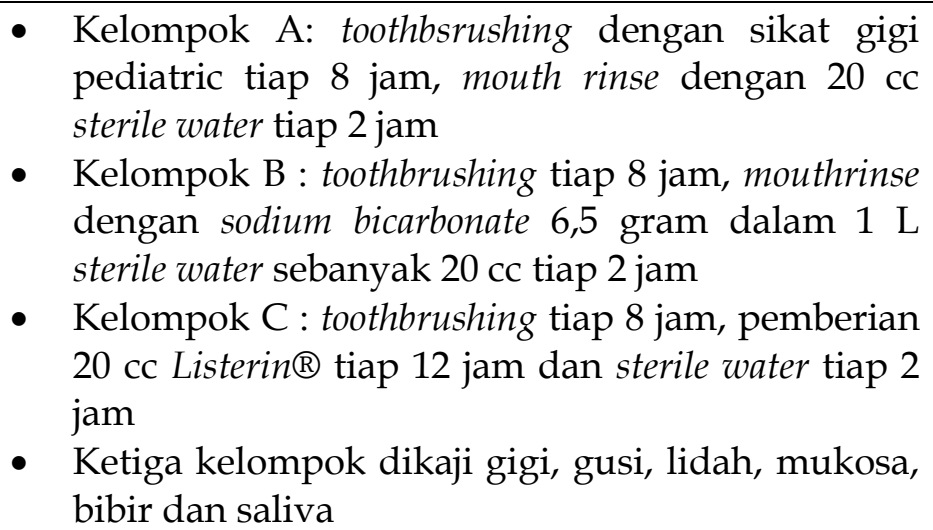 & $\begin{array}{l}\text { - Tidak ada perbedaan yang } \\
\text { signifikan kolonisasi plak } \\
\text { gigi pada hari ke-4 antara } \\
\text { ketiga kelompok }(p=0.243) \\
\text { - Tidak ada perbedaan } \\
\text { insidensi VAP antar ketiga } \\
\text { grup }(p=0,92)\end{array}$ \\
\hline $\begin{array}{c}\text { Pobo, et al (2009) } \\
\text { USA }\end{array}$ & $\begin{array}{l}\text { Single-blind, } \\
\text { prospective, } \\
\text { Randomized } \\
\quad \text { study }\end{array}$ & 147 & $\begin{array}{l}\text { - Kelompok standard care : } 0,12 \% \text { CHX swab } \\
\text { sebanyak } 20 \text { cc tiap } 8 \text { jam, mempertahankan HOB } \\
30 \text { derajat, kemudian } 10 \text { cc } 0,12 \% \text { CHX } \\
\text { dimasukkan kedalam rongga mulut dan } \\
\text { dilakukan suction setelah } 30 \text { detik } \\
\text { Kelompok toothbrush : oral care sama dengan } \\
\text { kelompok standard care, tetapi ditambah dengan } \\
\text { electric toothbrushing pada gigi, gusi dan lidah. }\end{array}$ & $\begin{array}{l}\text { - Tidak ada perbedaan yang } \\
\text { signifikan insiden VAP dari } \\
\text { kedua kelompok }(p=0,55) \\
\text { - Tidak ada perbedaan yang } \\
\text { signifikan angka mortalitas, } \\
\text { durasi ventilasi mekanik, } \\
\text { dan LOS }\end{array}$ \\
\hline
\end{tabular}


Literature review ini terdiri dari artikel yang memiliki heterogenitas larutan, alat pengkajian serta teknik oral care pada pasien intubasi trakea kasus trauma maupun non-trauma. Sehingga dapat dikategorikan menjadi beberapa topik isu meliputi larutan oral care, teknik pelaksanaan, peralatan dan waktu oral care, serta oral assessment tools pada pasien intubasi trakea.

\section{Larutan Oral Care}

Larutan yang digunakan dalam pelaksanaan oral care pasien dengan ventilasi mekanik dibagi menjadi 2 jenis, yaitu mouthwash dan moisturizer. Chlorhexidine gluconate merupakan larutan mouthwash yang paling banyak direkomendasikan. Chlorhexidine gluconate merupakan dekontaminasi oral, agen antiplak untuk menghambat aktifitas antimikroba tanpa menyebabkan resistensi yang tinggi terhadap mikroorganisme pada mulut (Sekino, 2004). Chlorhexidine gluconate direkomendasikan oleh sebagian besar author dari artikel yang direview. Hal ini dikarenakan Chlorhexidine memiliki spectrum yang luas dan sebagai anti pembentukan plak yang efektif (Yudanur,2016). Akan tetapi bentuk dari Chlorhexidine gluconate yang digunakan berbeda-beda. De Lacerda Vidal et al (2017) merekomendasikan penggunaan Chlorhexidine gluconate dalam bentuk gel, sedangkan Lorente (2012), Liao (2014), Estaji (2016), dan Pobo (2009) menggunakan Chlorhexidine gluconate bentuk cair. Selain itu, Ames (2011) menggunakan Chlorhexidine gluconate dalam bentuk spray.

Penggunaan Chlorhexidine gluconate sebagai mouthwash dalam bentuk cair lebih banyak direkomendasikan karena terbukti efektif dalam menurunkan nilai Clinical Pulmonari Infection Score (CPIS) (Grap, et al,2011). Fourier (2005) menyatakan bahwa Chlorhexidine spray ataupun cair efektif dalam mengurangi kolonisasi bakteri gram negatif yang berperan dalam infeksi paru. Selain Chlorhexidine gluconate, Prandergast, et al (2012) merekomendasikan larutan normal salin untuk mouthwash pada oral care. Meskipun normal saline terbukti efektif dalam menurunkan tingkat keparahan rongga oral, Yagmur (2016) menegaskan perlunya penelitian lebih lanjut terkait dengan efektifitas normal salin terhadap kolonisasi mikroorganisme maupun insiden VAP. Miler \& Kearney (2001) menyebutkan bahwa larutan oral care pada pasien kritis sebaiknya bersifat tidak mengiritasi mukosa, tidak menyebabkan kering, dan mampu membersihkan plak.

Konsentrasi Chlorhexidine gluconate (CHX) yang digunakan terdapat 3 macam konsentrasi yaitu $0,12 \%, 0,2 \%$, dan $2 \%$. Sebagian besar author merekomendasikan penggunaan Chlorhexidine 0,12\% telah terbukti efektif untuk memperbaiki skor kesehatan mulut, mengurangi skor CPIS, dan insidensi VAP. Sebagian author yang lain merekomendasikan penggunaan Chlorhexidine 0,2\% untuk menurunkan insiden VAP, memperbaiki skor kesehatan mulut dan menurunkan laju perkembangan bakteri. Evidence terkait penggunaan Chlorhexidine 2\% sangat terbatas. Luc (1998) dalam studi comparative menunjukkan bahwa tidak ada perbedaan aktifitas bakteri pada chlorhexidine dengan konsentrasi yang berbeda $(0,1 \%, 0,12 \%, 0,2 \%)$. Faktor yang mempengaruhi efektifitas anti-bakteri tersebut bukan karena konsentrasinya, tetapi pada faktor eksipiennya. Tuon (2017) juga menyatakan bahwa efek antimikroba pada chlorhexidine sudah aktif pada konsentrasi yang rendah. Bahkan penelitian Nerandzic \& Donskey (2015) menunjukkan bahwa chlorhexidine dengan konsentrasi rendah 0,0004\% efektif dalam mengurangi bakteri resisten Clostridium difficile.

Volume CHX dalam pelaksanaan oral care juga bervariasi. Beberapa author menggunakan 5 cc CHX, sebagian yang lain menggunakan 10-15 cc. Bahkan beberapa author tidak menyebutkan secara spesifik berapa volume CHX yang digunakan dalam penelitiannya. Sampai saat ini, belum ada penelitian terkait dengan volume CHX yang paling efektif untuk oral care pasien ventilasi mekanik. Akan tetapi, Grap (2011) menyebutkan bahwa penggunaan CHX sebanyak minimal 5 cc sudah cukup untuk melapisi rongga oral, meskipun volume CHX yang direkomendasikan sebagian besar author adalah maksimal 15cc. 
Selain mouthwash, penggunaan moisturizer mulai menjadi salah satu larutan esensial dalam pelaksanaan oral care. Ganz et al (2009) \& Hsu et al (2011) menyatakan bahwa agen oral moisturizer (pelembab mukosa dan bibir) menjadi salah satu metode untuk mempertahankan hidrasi oral pada pasien dengan intubasi trakea. Jones (2005) merekomendasikan Oral Balance ${ }^{\circledR}$ sebagai gel pelembab karena mengandung enzim antimikroba normal yang terdapat pada saliva, yaitu lactoperoxidase dan glukosa oksidase. Hasil penelitian Prandergast (2012) menunjukkan bahwa pelaksanaan oral care dengan memberikan agen pelembab bibir dapat memperbaiki skor kesehatan mulut, bahkan setelah ekstubasi. Akan tetapi, Ames (2011) dalam penelitiannya, menggunakan biotene ataupun air biasa sebagai pelembab pada bibir. Selain sebagai pelembab, penggunaan air sebagai mouthrinse setelah pelaksanaan toothbrush juga banyak dilakukan oleh beberapa author. Berry et al (2007) menyatakan bahwa penggunaan air biasa dapat menjadi sumber infeksi nosokomial, sehingga penggunaannya sebagai mouthrinse pada pelaksanaan oral care pasien dengan intubasi trakea perlu diganti. Penggunaan sterile water mungkin bisa menjadi pengganti mouthrinse, tetapi perlu dilakukan penelitian lebih lanjut.

\section{Teknik Oral Care}

Teknik dan alat pelaksanaan oral care pada pasien ventilasi mekanik juga berbeda-beda. Sebagian besar author merekomendasikan pelaksanaan oral care dengan menggunakan toothbrushing. Pelaksanaan toothbrushing ini bertujuan sebagai pembersihan mekanis plak pada gigi. Efektifitas pelaksanaan toothbrushing telah banyak ditunjukkan mampu menurnkan insiden VAP, memperbaiki skor kesehatan mulut, serta mikroorganisme oral (de Lacerda Vidal et el,2017; Lorente, 2012; Prendergast, 2012). Estaji, et al (2016) menyebutkan bahwa toothbrushing menjadi tindakan yang esensial dalam pelaksanaan oral care pada pasien dengan intubasi. Toothbrushing dilakukan pada gigi, gusi, palatum, serta lidah. Akan tetapi, toothbrushing harus dilakukan secara hati - hati agar tidak menyebabkan dislokasi selang ETT dan perdarahan (Ames, 2011). Maka dari itu, dalam penelitian Prendergast, et al (2012) dan Ames (2011) melakukan pengkajian bleeding terlebih dahulu sebelum pelaksanaan toothbrushing.

Alat yang digunakan untuk oral care juga berbeda-beda, tergantung teknik pelaksanaannya. Sikat gigi pediatric digunakan oleh sebagian besar author karena memiliki bulu sikat yang lembut serta ukuran yang dapat menjangkau rongga mulut pasien dengan intubasi trakea (de Lacerda Vidal et al, 2017; Liao,2014; Berry,2013). Ames (2011) merekomendasikan penggunaan sikat gigi ultrasoft pada pasien ventilasi mekanik. Haffajee, et al (2001) dan Heanue, et al (2003) menyatakan bahwa penggunaan sikat gigi elektrik lebih efektif dalam mengurangi plak dan meningkatkan kesehatan gingival.

Frekuensi oral care pasien ventilasi mekanik juga bervariasi, de Lacerda Vidal et al (2012) merekomendasikan oral care dilaksanakan tiap 12 jam, Sedangkan sebagian besar author merekomendasikan tiap 8 jam (Lorente, 2012; Liao et al, 2014; Estaji, 2016; Berry, 2013; Pobo, 2009). Ames (2011) menyatakan bahwa frekuensi oral care antar pasien berbeda-beda, tergantung kondisi kesehatan mulutnya. Maka dari itu, frekuensi oral care didasarkan pada skor oral assessment (BOAS), tetapi minimal diberikan tiap $12 \mathrm{jam}$. Selain itu, terdapat beberapa protocol penting dalam oral care, yaitu posisi Head of Bed $(\mathrm{HOB}) \geq 30^{\circ}$, pengecekan cuff ETT serta mempertahankan tekanan sebesar 20-24 mmHg, serta suction sebelum dan selama oral care.

\section{Oral Assessment Tools}

Dari review yang telah didapatkan, terdapat tiga alat pengkajian oral yang telah dikembangkan untuk pasien ventilasi mekanik. Prendergast (2012) memodifikasi pengkajian oral dari Eiler yang dikenal dengan Oral Assessment Guide (OAG). OAG terdiri dari 8 pengkajian yaitu pengkajian kemampuan menelan, bibir, lidah, saliva, membrane mukosa, gingival, gigi dan bau 
mulut. Author lain, Ames (2011) mengembangkan oral assessment tools yang disebut dengan Beck Oral Assessment Scale (BOAS) modifikasi yang mengkaji 5 subskala pengkajian yaitu bibir, gingival dan oral mukosa, lidah, gigi, dan saliva. BOAS original sebenarnya digunakan untuk pengkajian oral pasien stomatitis pada kasus onkologi. Ames menghilangkan 2 subscala (kualitas suara dan kemampuan menelan). Hal ini disesuaikan dengan kondisi pasien intubasi trakea dengan adanya selang ETT. Selain kedua alat pengkajian tersebut, alat pengkajian Mucosal-Plaque Score (MPS) menjadi pengkajian tambahan dari pengkajian rongga mulut. Pengembangan terkait alat pengkajian oral pada pasien ventilasi mekanik yang valid dan reliable perlu diteliti lebih lanjut.

\section{SIMPULAN}

Oral care pada pasien terpasang ventilasi mekanik merupakan intervensi utama dalam pencegahan infeksi oral. Hal ini dikarenakan mulut berperan sebagai gerbang utama masuknya infeksi. Oleh karena itu, pelaksanaan oral care pasien harus dilakukan secara komprehensif, meliputi pengkajian oral dengan assessment tools, pelaksanaan toothbrushing dengan antimikroba (CHX), membersihkan selang ETT, serta pemberian moisturizer. Selain itu, frekuensi pelaksanaan oral care disesuaikan dengan hasil pengkajian kesehatan mulut masing - masing pasien. Semua komponen tersebut ditujukan untuk mencegah kolonisasi mikroorganisme, sehingga insiden VAP pada pasien yang terpasang ventilasi mekanik dapat menurun.

\section{SARAN}

Peneliti merekomendasikan penelitian lanjutan tentang agen pelembab mukosa dan bibir alami yang dapat digunakan dalam tindakan oral care pada pasien terpasang ventilasi mekanik. Selain itu, diperlukan penelitian tentang perbandingan alat - alat pengkajian mulut pasien terpasang ventilasi mekanik untuk mengkonfirmasi alat pengkajian yang paling efektif digunakan di Indonesia.

\section{DAFTAR PUSTAKA}

American Dental Association.Oral Health Topics: Cleaning your teeth and gums (oral hygiene) diakses dari http://www.ada.org/public/topics/cleaning.asp. Diakses pada 1 Januari 2016.

Ames, N. J., Sulima, P., Yates, J. M., McCullagh, L., Gollins, S. L., Soeken, K., \& Wallen, G. R. (2011). Effects of systematic oral care in critically ill patients: a multicenter study. American Journal of Critical Care, 20(5), e103-e114.

Bagg, J., MacFarlane, T. W., Poxton, I. R., \& Smith, A. J. (2006). Essentials of microbiology for dental students (No. Ed. 2). Oxford university press.

Berry, A. M. (2013). A comparison of Listerine ${ }^{\circledR}$ and sodium bicarbonate oral cleansing solutions on dental plaque colonisation and incidence of ventilator associated pneumonia in mechanically ventilated patients: A randomised control trial. Intensive and Critical Care Nursing, 29(5), 275-281.

Berry, A. M., Davidson, P. M., Masters, J., \& Rolls, K. (2007). Systematic literature review of oral hygiene practices for intensive care patients receiving mechanical ventilation. American Journal of Critical Care, 16(6), 552-562.

Berry, A. M., Davidson, P. M., Masters, J., Rolls, K., \& Ollerton, R. (2011). Effects of three approaches to standardized oral hygiene to reduce bacterial colonization and ventilator associated pneumonia in mechanically ventilated patients: a randomised control trial. International journal of nursing studies, 48(6), 681-688.

Binkley, C., Furr, L. A., Carrico, R., \& McCurren, C. (2004). Survey of oral care practices in US intensive care units. American journal of infection control, 32(3), 161-169.

Chastre, J., \& Fagon, J. Y. (2002). Ventilator-associated pneumonia. American journal of respiratory and critical care medicine, 165(7), 867-903. 
de Lacerda Vidal, C. F., de Lacerda Vidal, A. K., de Moura Monteiro, J. G., Cavalcanti, A., da Costa Henriques, A. P., Oliveira, M., ... \& Gomes, B. (2017). Impact of oral hygiene involving toothbrushing versus chlorhexidine in the prevention of ventilator-associated pneumonia: a randomized study. BMC infectious diseases, 17(1), 112.

DeRiso AJ II., Ladowski JS., Dillon TA., Justice JW., Peterson AC. (1996). Chlorhexidine gluconate $0.12 \%$ oral rinse reduces the incidence of total nosocomial respiratory infection and nonprophylactic systemic antibiotic use in patients undergoing heart surgery. Chest.109(6):1556-1561.

Estaji, Z., Alinejad, M., Rakhshani, M. H., \& Rad, M. (2016). The comparison of chlorhexidine solution and swab with toothbrush and toothpaste effect on preventing oral lesions in hospitalized patients in intensive care unit. Global journal of health science, 8(5), 211.

Feider, L. L., Mitchell, P., \& Bridges, E. (2010). Oral care practices for orally intubated critically ill adults. American Journal of Critical Care, 19(2), 175-183.

Fitch, J. A., Munro, C. L., Glass, C. A., \& Pellegrini, J. M. (1999). Oral care in the adult intensive care unit. American Journal of Critical Care, 8(5), 314.

Fourrier, F., Dubois, D., Pronnier, P., Herbecq, P., Leroy, O., Desmettre, T., ... \& Roussel-Delvallez, M. (2005). Effect of gingival and dental plaque antiseptic decontamination on nosocomial infections acquired in the intensive care unit: a double-blind placebo-controlled multicenter study. Critical care medicine, 33(8), 1728-1735.

Ganz, F. D., Fink, N. F., Raanan, O., Asher, M., Bruttin, M., Nun, M. B., \& Benbinishty, J. (2009). ICU nurses' oral-care practices and the current best evidence. Journal of Nursing Scholarship, 41(2), 132-138.

Gibbons, R. J. (1989). Bacterial adhesion to oral tissues: a model for infectious diseases. Journal of dental research, 68(5), 750-760.

Grap, M. J., Munro, C. L., Ashtiani, B., \& Bryant, S. (2003). Oral care interventions in critical care: frequency and documentation. American Journal of Critical Care, 12(2), 113-118.

Grap, M. J., Munro, C. L., Hamilton, V. A., Elswick Jr, R. K., Sessler, C. N., \& Ward, K. R. (2011). Early, single chlorhexidine application reduces ventilator-associated pneumonia in trauma patients. Heart \& Lung: The Journal of Acute and Critical Care, 40(5), e115-e122.

Guide, H. T. (2012). Prevent ventilator-associated pneumonia. Cambridge, MA: Institute for Healthcare Improvement.

Haffajee, A. D., Thompson, M., Torresyap, G., Guerrero, D., \& Socransky, S. S. (2001). Efficacy of manual and powered toothbrushes (I). Effect on clinical parameters. Journal of Clinical Periodontology, 28(10), 937-946.

Heanue, M., Deacon, S. A., Deery, C., Robinson, P. G., Walmsley, A. D., Worthington, H. V., ... \& Shaw, B. C. (2003). Manual versus powered toothbrushing for oral health. Cochrane Database of Systematic Reviews, (1).

Houston, S., Hougland, P., Anderson, J. J., LaRocco, M., Kennedy, V., \& Gentry, L. O. (2002). Effectiveness of $0.12 \%$ chlorhexidine gluconate oral rinse in reducing prevalence of nosocomial pneumonia in patients undergoing heart surgery. American Journal of Critical Care, 11(6), 567-570.

Hsu, S. P., Liao, C. S., Li, C. Y., \& Chiou, A. F. (2011). The effects of different oral care protocols on mucosal change in orally intubated patients from an intensive care unit. Journal of clinical nursing, 20(7-8), 1044-1053.

Ibrahim, S. M., Mudawi, A. M., \& Omer, O. (2015). Nurses' knowledge, attitude and practice of oral care for intensive care unit patients. Open Journal of Stomatology, 5(07), 179.

Jones, H. (2005). Oral care in intensive care units: a literature review. Special Care in Dentistry, 25(1), 6-11.

Liao,Yu-Mei.Jung-Rung Tsai.,Fan-Hao Chou. (2014). The effectiveness of an oral health program for preventing ventilator-associated pneumonia.British Association of critical care nurses. 20(2): 8997. 
Lorente, L., Lecuona, M., Jiménez, A., Palmero, S., Pastor, E., Lafuente, N., ... \& Sierra, A. (2012). Ventilator-associated pneumonia with or without toothbrushing: a randomized controlled trial. European journal of clinical microbiology \& infectious diseases, 31(10), 2621-2629.

Luc, J., Mroz, C., Roques, C., \& Ducani-Federlin, M. (1998). The bactericidal activity of mouthwashes containing $0.10 \%, 0.12 \%$ and $0.20 \%$ chlorhexidine digluconate. Bulletin du Groupement international pour la recherche scientifique en stomatologie \& odontologie, 40(2-3), 102-108.

Miller, M. \& Kearney, N. (2001). Oral Care for Patients With Cancer: A Review of the literature. Cancer Nursing. 24: 241-254.

Nerandzic, M. M., \& Donskey, C. J. (2015). Induced sporicidal activity of chlorhexidine against Clostridium difficile spores under altered physical and chemical conditions. PloS one, 10(4), e0123809.

Pear, Suzanne., Kathleen Stoessel., Susan Shoemake. (2007).Oral care is critical care: the role of oral care in the prevention of hospital-acquired pneumonia.Registered Trademark or Trademark of Kimberly-Clark Worldwide, Inc.

Pobo, A., Lisboa, T., Rodriguez, A., Sole, R., Magret, M., Trefler, S., ... \& RASPALL Study Investigators. (2009). A randomized trial of dental brushing for preventing ventilatorassociated pneumonia. Chest, 136(2), 433-439.

Prendergast, V., Jakobsson, U., Renvert, S., \& Hallberg, I. R. (2012). Effects of a standard versus comprehensive oral care protocol among intubated neuroscience ICU patients: results of a randomized controlled trial. Journal of Neuroscience Nursing, 44(3), 134-146.

Rello, J., Koulenti, D., Blot, S., Sierra, R., Diaz, E., De Waele, J. J., ... \& Rodriguez, A. (2007). Oral care practices in intensive care units: a survey of 59 European ICUs. Intensive care medicine, 33(6), 1066-1070.

Sekino, S., Ramberg, P., Guzin Uzel, N., Socransky, S., \& Lindhe, J. (2004). The effect of a chlorhexidine regimen on de novo plaque formation. Journal of clinical periodontology, 31(8), 609-614.

Soh, Kim Lam, et al. (2012). Oral care practice for ventilated patient in intensive care units : a pilot survey. J Infect Dev Ctries, 6(4), 333-339.

Tablan, O. C., Anderson, L. J., Besser, R. E., Bridges, C. B., \& Hajjeh, R. A. (2004). Guidelines for preventing health-care-associated pneumonia, 2003; recommendations of CDC and the Healthcare Infection Control Practices Advisory Committee;[pt. II-III].

Tuon, F. F., Gavrilko, O., de Almeida, S., Sumi, E. R., Alberto, T., Rocha, J. L., \& Rosa, E. A. (2017). Prospective, randomised, controlled study evaluating early modification of oral microbiota following admission to the intensive care unit and oral hygiene with chlorhexidine. Journal of global antimicrobial resistance, 8, 159-163.

Yagmur, F. N. (2016). A recent view and evidence-based approach to oral care of intensive care patient. International Journal of Caring Sciences, 9(3), 1177. 